\title{
PENGARUH EDUKASI PENCEGAHAN PENULARAN COVID 19 TERHADAP PERILAKU ANAK ASUH
}

\author{
Helsy Desvitasari $^{1}$, M.Ramadhani Firmansyah ${ }^{2}$, Apriani $^{3}$ \\ 1,2,3. Program Studi Ilmu Keperawatan STIK Siti Khadijah \\ Email: desvitasarihelsy@gmail.com ramadhani2687@gmail.com \\ adies_dini@yahoo.co.id
}

\begin{abstract}
ABSTRAK
Latar belakang : Coronavirus Disease 2019 (COVID-19) adalah penyakit jenis baru yang belum pernah diidentifikasi sebelumnya pada manusia yang disebabkan oleh Sars-CoV-2. Tingginya angka kejadian Covid 19 diberbagai belahan dunia menjadi tantangan bagi tenaga kesehatan dan pendidik untuk dapat berpartisipasi aktif dalam menggalakkan program pencegahan penularan Covid 19 salah satunya melalui gerakan cuci tangan pakai sabun. Tujuan : Mengetahui pengaruh edukasi pencegahan penularan Covid 19 terhadap perilaku anak asuh di panti asuhan $\mathrm{Al}$ - Fatih palembang. Metode : Jenis penelitian ini bersifat pre eksperimen dengan pendekatan one group pre-post test design dengan menggunakan uji wilxocon. Populasi dalam penelitian ini adalah anak asuh Panti Asuhan Al Fatih Palembang. Sampel penelitian ini adalah seluruh anak asuh yang berjumlah 31 orang. Penelitian ini dilakukan tanggal 29 Desember 2020. Hasil : Ada pengaruh edukasi pencegahan penularan Covid 19 terhadap pengetahuan anak asuh di panti asuhan $\mathrm{Al}$ - Fatih palembang dengan nilai $\mathrm{p}$ 0,001, ada pengaruh edukasi pencegahan penularan Covid 19

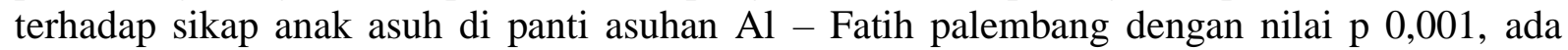
pengaruh edukasi pencegahan penularan Covid 19 terhadap keterampilan anak asuh di panti asuhan Al - Fatih palembang dengan nilai p 0,001. Saran : Bagi anak asuh hendaknya senantiasa untuk dapat menerapkan kebiasaan cuci tangan sebelum dan setelah melakukan aktivitas.
\end{abstract}

Kata Kunci : edukasi, pengetahuan, sikap, keterampilan

\begin{abstract}
Background: Coronavirus Disease 2019 (COVID-19) is a new type of disease that has never been previously identified in humans caused by Sars-CoV-2. The high incidence of Covid 19 in various parts of the world is a challenge for health workers and educators to be able actively participate in promoting prevention programs for the transmission of Covid 19, one of which is through the movement of washing hands with soap. Aim : To determine the effect of education on preventing the transmission of Covid 19 on the behavior of foster children at the $\mathrm{Al}$ - Fatih orphanage in Palembang. Method: This type of research is pre-experimental with one group pre-post test design approach using the Wilxocon test. The population in this study was the foster children of the Al Fatih Orphanage in Palembang. The sample of this study were all foster children totaling 31 people. This research was conducted on December 29, 2020. Results: There is an effect of education on preventing the transmission of Covid 19 on the knowledge of foster children at the $\mathrm{Al}$ - Fatih orphanage in palembang with a p value of 0.001 , there is an effect of education on preventing the transmission of Covid 19 on the attitudes of foster children at the $\mathrm{Al}$ - Fatih orphanage palembang with a p value of 0.001 , there is an effect of education on preventing the transmission of Covid 19 on the skills of foster children at the $\mathrm{Al}$ - Fatih orphanage in palembang with a p value of 0.001 . Suggestion: Foster children should always be able to apply the habit of washing hands before and after doing activities.
\end{abstract}

Keywords: Education, Knowledge, Attitudes, Skills

Volume XI No. 1 Juni $2021 \mathrm{Hal}-17$ 


\section{PENDAHULUAN}

Coronavirus Disease 2019 (COVID-19) adalah penyakit jenis baru yang belum pernah diidentifikasi sebelumnya pada manusia. Virus penyebab COVID-19 ini dinamakan Sars-CoV-2. Virus corona adalah zoonosis (ditularkan antara hewan dan manusia). Dua jenis coronavirus yang diketahui menyebabkan penyakit yang dapat menimbulkan gejala berat seperti Middle East Respiratory Syndrome (MERS) dan Severe Acute Respiratory Syndrome (SARS) (Kemenkes RI, 2019).

Angka kejadian penderita covid 19 Dunia berjumlah 30.675 .675 orang di 215 negara terjangkit dan 180 negara transmisi local. Sedangkan angka kejadian covid 19 Regional Asia Tenggara berjumlah 6.073.462 orang. Provinsi Sumatera Selatan berjumlah 5331 orang positif 71 orang (Kemkes, 2020)

Kota Palembang merupakan ibu kota Sumatera Selatan dengan jumlah kasus tertinggi diantara daerah lainnya dengan jumlah pederita positif terkonfirmasi sebanyak 2883 orang dengan dan kecamatan dengan jumlahsuspek terbanyak berjumlah 1181 orang yaitu berada di kecamatan ilir barat I (Dinkes Kota Palembang, 2020).

Data diperoleh dari Gugus Tugas percepatan penaganan Covid 19 kota Palembang bulan September 2020 memaparkan sebanyak 2883 jiwa yang dinyatakan terkonfirmasi dalam rentang usia $>70$ tahun sebanyak 23 orang, usia 6069 sebanyak 106 orang, usia 55-59 tahun sebanyak 84 orang,, usia 45-54 sebanyak 205 orang, usia 20-44 sebanyak 921 orang, usia 15-19 sebanyak 73 orang, usia 10-14 sebanyak 48 orang, usia 5-9 sebanyak 44 orang, usia 0-4 tahun sebanyak 36 orang. Paparan data tersebut menunjukkan bahwa anak dan remaja tidak luput dari penyakit ini.

Tingginya angka kejadian covid 19 diperlukannya tindakan preventif salah satunya pemberian edukasi kepada anak asuh sebagai "agen perubahan" dengan penerapan perilaku sehat melalui gerakan mencuci tangan. Kegiata edukasi di berikan dalam bentuk penyampaian pendidikan kesehatan terhadap masyarakat, terdiri dari tiga metode yaitu metode pendidikan individual, metode pendidikan kelompok dan metode pendidikan masa. Pendidikan kesehatan dapat lebih dipahami oleh peserta dengan bantuan media. Media pendidikan kesehatan merupakan alat yang digunakan oleh petugas kesehatan dalam menyampaikan bahan materi atau pesan kesehatan. (Notoatmodjo, 2014).

Panti asuhan adalah lembaga usaha kesejahteraan social yang memiliki tanggung jawab untuk memberikan pelayanan kesejahteraan social pada anak dengan melaksanakan kegiatan penyantunan dan pengentasan anak terlantar sekaligus sebagai pengganti orang tua/wali anak dalam memenuhi kebutuhan fisik, mental dan social anak yang diharapkan dapat menjadi sarana dalam membangun generasi bangsa dalam mendukung pembangunan nasional (Depsos RI, 2020). Salah satu Panti Asuhan yang ada di kota Palembang adalah panti asuhan Al-Fatih yang berlokasi di Jl. Lunjuk Jaya No. 293 Kel. Lorok Pakjo Kec. Ilir Barat I. panti asuhan ini terdiri dari 4 orang pengurus dan anak asuh sebanyak 31 orang.

Berdasarkan informasi yang didapatkan bahwa selama kejadian covid 19 merebak di Indonesia panti asuhan $\mathrm{Al}$ - Fatih belum pernah memperoleh informasi secara langsung dalam mencegah terjadinya covid 19 salah satunya edukasi tentang cuci 
tangan secara langsung di panti. Beberapa anak asuh juga mengatakan pernah mendapatkan edukasi cuci tangan di sekolah tetapi hanya sekilas saja. Dari 5 anak yang di wawancara di panti diperoleh informasi bahwa kegiatan mencuci tangan hanya dilakukan saat mau makan saja dan slesai BAK \& BAB. Hasil observasi di panti tidak adanya sarana cuci tangan di luar gedung bangunan panti.

Berdasarkan hasil penelitian yang dilakukan oleh Handayani dan Mariana (2020) didapatkan hasil bahwa ada pengaruh media audio visual cuci tangan terhadap kemampuan cuci tangan penghuni panti asuhan Nimas Ayu Pembayun Palembang.

Informasi penelitian lain dari Nurmaliza, dkk (2021) yang menunjukkan bahwa adanya peningkatan pengetahuan anakanak dilihat dari nilai pre dan pst test yaitu sebesar $40 \%$ meningkat menjadi $80 \%$ setelah mendapatkan penyuluhan tentang cuci tangan, hasil lainnya juga diperoleh informasi bahwa mayoritas anak - anak akan melakukan cuci tangan setiap akan memulai aktivitas diluar rumah.

Hasil penelitian lainnya yakni dari Glabska dkk. (2020) yang dilakukan pada anak sekolah menunjukkan bahwa frekuensi mencuci tangan selama masa pandemic Covid 19 secara signifikan lebih tinggi dari sebelumnya mayoritas responden menyatakan melakukan kegiatan cuci tangan $6-15$ kali sehari $(58,4 \%)$ sedangkan sebelum pandemic 3-10 kali sehari $(68,1 \%)$. Presentase responden yang melakukan kegiatan cuci tangan lebih tinggi dilakukan di periode pandemic Covid 19 (54\%) dibandingkan dengan periode sebelum Covid 19 terjadi (54,8\% dengan nilai $(\mathrm{p}<0,0001)$.

Berdasarkan uaraian diatas maka penulis tertarik untuk melakukan penelitian dengan judul pengaruh edukasi pencegahan penularan Covid 19 terhadap perilaku anak asuh di panti asuhan $\mathrm{Al}$ - Fatih palembang.

\section{METODE PENELITIAN}

Rancangan yang digunakan dalam penelitian ini adalah Pre Experimental dengan one grouppre post test design. Desain ini menggunakan satu kelompok, dengan memberikan intervensi edukasi pencegahan covid 19.

Subjek penelitian ini adalah seluruh anak asuh di Panti Asuhan Al-Fatih dengan jumlah sampel sebanyak 31 orang anak asuh dengan teknik pengambilan sampel menggunakan total sampling.

Instrumen yang digunakan adalah kuesioner pengetahuan dan sikap, lembar checklist keterampilan. Pengujian statistik penelitian ini menggunakan analisis nonparametrik (uji Wilcoxon test), dengan kemaknaan hasil uji ditentukan berdasarkan nilai $\mathrm{p}<0,05$.

\section{HASIL PENELITIAN}

\subsection{Analisis Univariat}

a. Distribusi frekuensi pre test dan post tes pengetahuan anak asuh

Tabel 1

Distribusi frekuensi pengetahuan sebelum diberikan edukasi

\begin{tabular}{llcc}
\hline No & $\begin{array}{c}\text { Pengetahuan } \\
\text { Sebelum } \\
\text { edukasi }\end{array}$ & Jumlah & Persentase \\
\hline 1 & Sangat baik & 7 & $22,6 \%$ \\
2 & Baik & 8 & $25,8 \%$ \\
3 & Cukup & 11 & $35,5 \%$ \\
4 & Kurang & 5 & $16,1 \%$ \\
\hline & Total & 31 & $100 \%$ \\
\hline
\end{tabular}

Berdasarkan tabel diatas diketahui bahwa dari 31 responden sebelum di berikan 
edukasi memiliki pengetahuan tertinggi pada kategori cukup sebanyak 11 (35,5\%) responden sedangkan pengetahuan terendah terdapat pada kategori kurang sebanyak 5 $(16,1 \%)$

Tabel 2

Distribusi frekuensi pengetahuan sesudah diberikan edukasi

\begin{tabular}{clcc}
\hline No & $\begin{array}{c}\text { Pengetahuan } \\
\text { Setelah } \\
\text { edukasi }\end{array}$ & Jumlah & Persentase \\
\hline 1 & Sangat baik & 17 & $54,8 \%$ \\
2 & Baik & 9 & $29 \%$ \\
3 & Cukup & 5 & $16,1 \%$ \\
\hline & Total & 31 & $100 \%$ \\
\hline
\end{tabular}

Berdasarkan tabel 2 diketahui bahwa dari 31 responden sesudah diberikan edukasi pengetahuan meningkat pada kategori sangat baik sebanyak $17(54,8 \%)$ responden sedangkan pengetahuan terendah terdapat pada kategori cukup sebanyak $5(16,1 \%)$.

b. Distribusi frekuensi pre test dan post tes sikap anak asuh

Tabel 3

Distribusi frekuensi sikap sebelum diberikan edukasi

\begin{tabular}{llcc}
\hline No & $\begin{array}{c}\text { Sikap } \\
\text { Sebelum } \\
\text { edukasi }\end{array}$ & Jumlah & Persentase \\
\hline 1 & $\begin{array}{l}\text { Sangat } \\
\text { baik }\end{array}$ & 6 & $19,4 \%$ \\
2 & Baik & 17 & $54,8 \%$ \\
3 & Cukup & 5 & $16,1 \%$ \\
4 & Kurang & 3 & $9,7 \%$ \\
\hline & Total & 31 & $100 \%$ \\
\hline
\end{tabular}

Berdasarkan tabel 3 diketahui bahwa dari 31 responden sebelum di berikan edukasi sikap dominan yang ditunjukkan terbanyak pada kategori baik berjumlah 17 (54,8\%).
Tabel 4

Distribusi frekuensi sikap sesudah diberikan edukasi

\begin{tabular}{clcc}
\hline No & $\begin{array}{c}\text { Sikap } \\
\text { Setelah } \\
\text { edukasi }\end{array}$ & Jumlah & Persentase \\
\hline 1 & $\begin{array}{l}\text { Sangat } \\
\text { baik }\end{array}$ & 18 & $58,1 \%$ \\
2 & Baik & 11 & $35,5 \%$ \\
3 & Cukup & 2 & $6,5 \%$ \\
\hline & Total & 31 & $100 \%$ \\
\hline
\end{tabular}

Berdasarkan tabel 4 diketahui bahwa dari 31 responden sesudah di berikan edukasi menunjukkan perubahan sikap menjadi sangat baik yaitu sebanyak $18(58,1 \%)$.

c. Distribusi frekuensi pre test dan post tes psikomotrik anak asuh

Tabel 5

Distibusi frekuensi psikomotorik Sebelum diberikan edukasi

\begin{tabular}{llcc}
\hline No & $\begin{array}{c}\text { Psikomotorik } \\
\text { Sebelum } \\
\text { edukasi }\end{array}$ & Jumlah & Persentase \\
\hline 1 & Sangat baik & 7 & $22,6 \%$ \\
2 & Baik & 8 & $25,8 \%$ \\
3 & Cukup & 11 & $35,5 \%$ \\
4 & Kurang & 5 & $16,1 \%$ \\
\hline & Total & 31 & $100 \%$ \\
\hline
\end{tabular}

Berdasarkan tabel 5 diketahui bahwa dari 31 responden sebelum di berikan edukasi menunjukkan psikomotorik (keterampilan) dominan yang pada kategori cukup sebanyak $11(35,5 \%)$ responden.

Tabel 6

Distibusi frekuensi psikomotorik Sesudah diberikan edukasi

\begin{tabular}{clcc}
\hline No & $\begin{array}{c}\text { Psikomotorik } \\
\text { Setelah } \\
\text { edukasi }\end{array}$ & Jumlah & Persentase \\
\hline 1 & Sangat baik & 25 & $80,6 \%$ \\
2 & Baik & 6 & $19,4 \%$ \\
\hline & Total & 31 & $100 \%$ \\
\hline
\end{tabular}


Berdasarkan table 6 diketahui bahwa dari 31 responden sesudah di berikan edukasi menunjukkan psikomotorik (keterampilan) meningkat menjadi sangat baik yaitu berjumlah $25(80,6 \%)$ responden.

\subsection{Analisa Bivariat}

\section{a. Pengaruh edukasi terhadap pengetahuan anak asuh di Panti Asuhan Al Fatih Palembang}

Tabel 7

Pengaruh edukasi terhadap pengetahuan anak asuh

\begin{tabular}{lccc}
\hline $\begin{array}{c}\text { Variable } \\
\text { Pengetahuan }\end{array}$ & Mean & $\mathbf{Z}$ & Sig. \\
\hline Pre test-post & $2.45-$ & - & .001 \\
test & 1.61 & $3.570^{\mathrm{a}}$ & \\
\end{tabular}

$P<0,05$ Based on Wilcoxon test

Berdasarkan tabel diatas diperoleh nilai $\mathrm{z}$ hitung $-3.570^{\mathrm{a}}$ pada peluang kesalahan sebesar 0,001. Hal ini menunjukkan bahwa ada perbedaan tingkat pengetahuan sebelum dan sesudan diberika edukasi.

b. Pengaruh edukasi terhadap sikap anak asuh di Panti Asuhan Al Fatih Palembang

Table 8

Pengaruh edukasi terhadap sikap anak asuh

\begin{tabular}{lccc}
\hline $\begin{array}{l}\text { Variable } \\
\text { Sikap }\end{array}$ & Mean & $\mathbf{Z}$ & Sig. \\
\hline Pre test- & $2.16-$ & - & .001 \\
post test & 1.48 & $3.700^{\mathrm{a}}$ &
\end{tabular}

$P<0,05$ Based on Wilcoxon test

Berdasarkan tabel diatas diperoleh nilai $\mathrm{z}$ hitung $-3.700^{\mathrm{a}}$ pada peluang kesalahan sebesar 0,001 . Hal ini menunjukkan bahwa ada perbedaan sikap sebelum dan sesudan diberika edukasi.
c. Pengaruh edukasi terhadap psikomotorik anak asuh di Panti Asuhan Al Fatih Palembang

\section{Table 8}

Pengaruh edukasi terhadap psikomotorik anak asuh

\begin{tabular}{lccc}
\hline \multicolumn{1}{c}{ Variable } & Mean & $\mathbf{Z}$ & Sig. \\
Psikomotorik & & & \\
\hline Pre test-post & $2.45-$ & - & .001 \\
test & 1.19 & $4.281^{\mathrm{a}}$ & \\
& & & \\
\hline & & & \\
\hline 05 Based on Wilcoxon test
\end{tabular}

Berdasarkan tabel diatas diperoleh nilai $\mathrm{z}$ hitung $-4.281^{\mathrm{a}}$ pada peluang kesalahan sebesar 0,001. Hal ini menunjukkan bahwa ada perbedaan psikomotorik sebelum dan sesudan diberika edukasi.

\section{PEMBAHASAN}

a. Pengaruh edukasi terhadap pengetahuan anak asuh di Panti Asuhan $\mathrm{Al}$ - Fatih Palembang

Hasil penelitian menunjukkan bahwa terjadi peningkatan pengetahuan setelah diberikan edukasi, dimana pengetahuan sebelum diberikan edukasi tertinggi pada kategori cukup sebanyak 35,5\% meningkat menjadi sangat baik sebesar $54,8 \%$ setelah diberikan edukasi dengan nilai p 0,001 .

Pengetahuan akan menimbulkan kesadaran dan akhirnya akan menyebabkan seseorang berperilaku sesuai dengan pengetahuan yang dimilikinya (Notoatmodjo, 2010).

Rogers (1974) menyatakan bahwa pengetahuan sangat mempengaruhi tindakan seseorang daripada tindakan yang tidak didasari pengetahuan. Beliau juga mengemukakan bahwa seseorang sebelum mengadopsi perilaku baru, seseorang 
tersebut harus melalui proses yang berurutan antara lain :

a. Awareness (kesadaran), di mana orang tersebut menyadari dan mengetahui terlebih dahulu stimulus dari suatu objek.

b. Interest (merasa tertarik) terhadap stimulus atau objen tersebut. Disini sikap subjek sudah mulai timbul.

c. Evaluation (mengevaluasi) terhadap baik atau tidaknya suatu stimulus tersebut untuk dirinya.

d. Trail, subjek sudah mulai mencoba melakukan sesuatu sesuai dengan pengetahuan, kesadaran dan sikapnya terhadap stimulus.

e. Adoption, subjek telah berperilaku baru sesuai dengan pengetahuan, kesadaran dan sikapnya terhadap stimulus yang ada.

Hasil penelitian ini sejalan dengan penelitian yang dilakukan oleh Hikmah, E. (2019). Bahwa adanya perbedaan bermakna pengetahuan siswa sebelum dan sesudah mencuci tangan dengan $\mathrm{p}$ value 0,000 .

Hasil penelitian lainnya dari Ashari dkk (2020). Bahwa ada perbedaan pengetahuan sebelum dan sesudah senam cuci tangan pakai sabun dengan nilai $\mathrm{p}$ 0,025 .

Berdasarkan hasil penelitan terdapat perbedaan pengetahuan anak asuh sebelum dan sesudah diberikan edukasi. Anak asuh yang mendapatkan informasi secara langsung terkhusus terhadap suatu keterampilan mencuci tangan sesuai dengan tahapan atau langkah yang dianjurkan oleh pemerintah lebih termotivasi untuk mengetahui pentingnya mencuci tangan sebelum beraktivitas. b. Pengaruh edukasi terhadap sikap anak asuh di Panti Asuhan Al - Fatih Palembang

Hasil penelitian ini juga menunjukkan bahwa edukasi cuci tangan pakai sabun mempengaruhi sikap anak asuh. Hasil penilaian sikap dapat dilihat tetinggi pada kategori baik $54,8 \%$ sebelum di berikan edukasi, namun setelah diberikan edukasi sikap yang ditunjukkan anak asuh menjadi lebih positif yakni menjadi sangat baik $58,1 \%$ dengan nilai $\mathrm{p} 0,001$.

Sikap merupakan reaksi atau suatu respon emosional (emotional feeling) seseorang terhadap stimulus atau objek diluarnya dan penilainya gkgini dilanjutkan dengan kecenderungan atau tidak melakukan terhadap objek (Notoatmodjo, 2005).

Hasil penelitian ini sejalan dengan yang dilakukan oleh Wikurendra, E. A. (2018) menunjukkan bahwa adanya pengaruh cuci tangan pakai sabun terhadap sikap mencuci tangan pada siswa.

Hasil peneitian lainnya yang dilakukan oleh Aeni, Q., (2015) menunjukkan bahwa ada pengaruh yang signifikan antara pendidikan kesehatan terhadap sikap siswa tetang perilaku hidup bersih dan sehat.

Hasil penelitian ini menunjukkan adanya perubahan sikap yang bermakna setelah mendapatkan edukasi. Adanya proses interaksi antar anak asuh, anak asuh dan penyuluh dapat menumbuhkan sikap positif dalam melakukan impelmentasi cuci tangan sebelum beraktivitas.

Selain itu juga adanya specific feedback yang diberikan penyuluh kepada anak asuh memberikan motivasi tersendiri kepada anak asuh yang menyebabkan terjadinya perubahan sikap, dengan adanya perubahan sikap tersebut diharapkan dapat meningkatkan tingkat interest anak asuh 
dalam menjaga kebersihan diri guna mencegah penularan covid 19.
c. Pengaruh
edukasi terhadap
psikomotorik anak asuh di Panti

Asuhan Al - Fatih Palembang

Hasil penelitian menunjukkan bahwa melalui pemberian edukasi mempengaruhi psikomotorik anak asuh. Hasil penelitian didapatkan bahwa sebelum diberikan edukasi psikomotorik anak asuh dominan pada kategori cukup $35,5 \%$ dengan nilai $p$ 0,001 .

Psikomotorik merupakan sebuah ranah yang berkaitan erat dengan keterampilan dan kemampuan seseorang dalam menerima pengalaman belajar tertentu. Dimana hasil belajar psikomotorik ini merupakan kelanjutan dari hasil belajar kognitif dan afektif (Sudijono 2006).

Perkembangan kemampuan psikomotorik dapat terlihat melalui enam gerakan berikut : gerakan reflex, gerakan basic, kemampuan mengamati, kemampuan fisik, gerakan keterampilan dan gerakan komunikatif (Harrow, 1972; Rahyubi, 2014).

Hasil penelitian ini sejalan dengan penelitian yang dilakukan oleh Hikmah, E. (2019). Bahwa adanya perbedaan bermakna terhadap keterampilan siswa sebelum dan sesudah mencuci tangan dengan $p$ value 0,000 .

Hasil penelitian lain yang dilakukan oleh Trijayanti (2019). Didapatkan bahwa tindakan siswa terhadap cuci tangan pakai sabun terkategori baik yakni sebesar $66,7 \%$.

Dari hasil penelitian tersebut menunjukkan bahwa melalui kegiatan edukasi dapat meningkatkan keterampilan psikomotorik pada tahapan demonstration dapat memberikan kontribusi yang baik. Pada tahapan itu anak asuh diberikan kesempatan untuk mencoba dan akhirnya memperlancar semua proses esensial untuk menghasilkan kinerja yang terkoordinasi. Menurut Nursalam (2008) bahwa kondisi untuk mempelajari suatu keterampilan memerlukan panduaan dari pendidik, yang dapat memberikan pengalaman praktik kepada peserta didik, memberikan arahan apa saja yang harus dilakukan, bagaimana prosedur suatu tindakan, dan melakukan praktik sesuai dengan teknik procedural dan interpersonal.

Perubahan kemampuan psikomotorik tersebut tentunya mengikuti tahapan dari psikomotorik itu sendiri dimulai dari bagaimana anak asuh mempersepsikan suatu objek, menyiapkan fisik dan emosional, mempelajari keterampilan atau tindakan yang akan dilakukan melalui prosedur dan mekanisme yang terstandar, serta dapat berkarya dan berinovasi dalam melakukan suatu tindakan.

Melalui gerakan mencuci tangan pakai sabun yang mana sabun memiliki kandungan senyawa surfaktan sehingga saat bertemu lipid dan struktur genetic viruspun akan hancur dengan lamanya waktu kegiatan 20 detik dan di siram menggunakan air. Melalui gerakan mencuci tangan dapat menjadi salah satu wujud peran serta masyarakat dalam melakukan tindakan pencegahan penularan copid 19 saat ini.

\section{KESIMPULAN}

Berdasarkan hasil analisis dan pembahasan diatas maka dapat disimpulkan sebagai berikut :

Kegiatan edukasi memiliki pengaruh dalam meningkatkan pengetahuan, sikap dan psikomotorik anak asuh di Panti Asuhan Al Fatih Palembang. 
Aeni, Q., Beniarti, F., \& Warsito, B. E. (2015). Pengaruh pendidikan kesehatan dengan metode pemutaran video tentang phbs cuci tangan terhadap pengetahuan dan sikap. Jurnal keperawatan, 7(2), 15.

Andareto,Obi.(2015).Penyakit Menular Di Sekitar Anda.Jakarta;Pustaka Ilmu Semesta

Ashari, A. E., Ganing, A., \& Mappau, Z. (2020). Peningkatan Pengetahuan, Sikap dan Praktik Cuci Tangan Pakai Sabun pada Anak Kelas V Sekolah Dasar melalui Senam Cuci Tangan Pakai Sabun. Jurnal Ilmiah Permas: Jurnal Ilmiah STIKES Kendal, 10(1), 11-18.

Asmin dan A. Mansyur. (2014). Pengukuran dan Penilaian Hasil Belajar dengan. Analisis Klasik dan Modern. Medan: LARISPA

Azwar,Saifuddin.(2016).Sikap dan perilaku.Pustaka Pelajar. Yogyakarta

Dahlan, M. Sopiyudin. (2014). Statistik untuk Kedokteran dan Kesehatan: Deskriptif, Bivariat, dan Multivariat. Jakarta: Epidemologi Indonesia.

Depkes Kota Palembang (2020). Situasi Covid di Sum-Sel. Palembang : Depkes Sum-Sel

Depkes Provinsi Sumsel (2020). Situasi Covid di Sum-Sel. Palembang : Depkes Sum-Sel

Dinas kesehatan Kota Palembang.(2020). Profil Kesehatan Kota Palembang 2020. Palembang :Dinkes Kota.
Doli, Jenita. (2016). Metodologi Penelitian Keperawatan. Yogyakarta : Pustaka Baru Press.

Fitriani, Sinta. 2(011). Promosi Kesehatan. Yogyakarta : Graha Ilmu.

Głąbska, D., Skolmowska, D., \& Guzek, D. (2020). Population-based study of the influence of the COVID-19 pandemic on hand hygiene behaviors-Polish adolescents' COVID-19 experience (PLACE-19) study. Sustainability, 12(12), 4930.

Han Y, Yang H. The transmission and diagnosis of 2019 novel coronavirus infection disease (COVID-19): A Chinese perspective. J Med Virol. 2020; published online March 6. DOI: $10.1002 /$ jmv.25749

Handayani, M., \& Mariana, D. (2020). Pengaruh media audio visual cuci tangan terhadap kemampuan cuci tangan sebagai upaya pencegahan penyebaran virus covid19. Jurnal'Aisyiyah Medika, 6(1).

Hikmah, E. (2019). Pengaruh Terapi Bermain Puzzle Terhadap Pengetahuan, Sikap Dan Keterampilan Mencuci Tangan Pada Anak Di Sd Taman Sukaria I Kota Tangerang. Jurnal Medikes (Media Informasi Kesehatan), 6(1), 77-90.

Kementrian Kesehatan RI. (2019). Profil Kesehatan Indonesia 2017. Jakarta: Kemenkes RI. Diakses pada tanggal 7 September 2020

Kementrian Kesehatan RI. (2020). Pedoman Percepatan Penanganan Covid $19 \quad$ Revisi 5. 
Jakarta: Kemenkes RI. Diakses pada tanggal 28 September 2020.

Kementrian Sosial RI, (2020). Petunjuk Teknis Pelayanan Sosial. Jakarta : Kemsos RI. Diakses pada tanggal 14 September 2020.

Li G, Fan Y, Lai Y, Han T, Li Z, Zhou P, et al. Coronavirus infections and immune responses. J Med Virol. 2020;92(4):424-32.

Liu Y, Gayle AA, Wilder-Smith A, Rocklöv J. The reproductive number of COVID-19 is higher compared to SARS coronavirus. J Travel Med. 2020;27(2).

Notoatmodjo, S. (2014). Ilmu Perilaku Kesehatan. Jakarta: Rineka Cipta.

Notoatmodjo.(2014). Metodologi Penelitian Kesehatan.Jakarta : PT. Rineka Cipta.

Nurmaliza, N., Siagian, D. S., Herlina, S., Qomariah, S., Sartika, W., \& Ratih, R. H. (2021). Cuci Tangan yang Benar Mencegah Penyebaran COVID-19 di RT01/RW01 Desa Sungai Segajah Jaya Kabupaten Rokan Hilir. Indonesia Berdaya, 2(1), 77-85.

Pungki, y. A. D. (2017). Pengaruh pelatihan cuci tangan pakai sabun (ctps) terhadap perilaku mencuci tangan pada anak sekolah dasar di sdn mangge 2 desa mangge kecamatan barat kabupaten magetan tahun 2017 (doctoral dissertation, stikes bhakti husada mulia).

Qin C, Zhou L, Hu Z, Zhang S, Yang S, Tao $\mathrm{Y}$, et al. Dysregulation of immune response in patients with COVID-19 in Wuhan, China. Clin Infect Dis.
2020; published online March 12. DOI: $10.1093 / \mathrm{cid} / \mathrm{ciaa} 248$.

Riedel S, Morse S, Mietzner T, Miller S. Jawetz, Melnick, \& Adelberg's Medical Microbiology. 28th ed. New York: McGrawHill Education/Medical; 2019. p.617-22.

Trijayanti, D. A. K. L. (2019). Perilaku Tentang Cuci Tangan Pakai Sabun Di Madrasah Ibtidaiyah Taswirul Afkar. Jurnal Promkes: The Indonesian Journal of Health Promotion and Health Education, 7(1), 46-55.

Van Doremalen N, Bushmaker T, Morris DH, Holbrook MG, Gamble A, Williamson BN, et al. Aerosol and Surface Stability of SARS-CoV-2 as Compared with SARS-CoV-1. N Engl J Med. 2020; published online March $17 . \quad$ DOI: 10.1056/NEJMc2004973

Wikurendra, E. A. (2018). Pengaruh Penyuluhan Cuci Tangan Pakai Sabun Terhadap Sikap Mencuci Tangan Siswa. Jurnal Ilmiah Kesehatan Media Husada, 7(2), 6469.

World Health Organization (WHO).2020. Advice for public. https://www.who.int/emergencies/d iseases/novel-coronavirus2019/advice-for-public.Diakses 20 September 2020

World Health Organization (WHO).2020. situation report. https://www.who.int /emergencies/diseases/novelcoronavirus-2019/situation-reports. Diakses 20 September 2020

World Health Organization (WHO).2020. situation report. https://www.who.int/emergencies/d 
iseases/novel-coronavirus-

2019/situation-reports. Diakses 20

September 2020

World Health Organization (WHO).2020.

WHO recommendations to reduce risk of transmission of emerging pathogens from animals to humans in live animal markets. https://www.who.int/healthtopics/coronavirus/whorecommendations-to-reduce-riskoftransmission-of-emergingpathogens-from-animals-tohumans-in-live-animal-markets. Diakses 20 September 2020

Xiao F, Tang M, Zheng X, Liu Y, Li X, Shan H. Evidence for gastrointestinal infection of SARSCoV-2. Gastroenterology. 2020; published online March 3. DOI: 10.1053/j.gastro.2020.02.055

Zhang H, Penninger JM, Li Y, Zhong N, Slutsky AS. Angiotensinconverting enzyme2(ACE2)asa SARS-CoV-2 receptor: molecular mechanisms and potential therapeutic target. Intensive Care Med. 2020; published online March 3. DOI: 10.1007/s00134-020059 